\title{
Biomarkers in the stratified water column of the Landsort Deep (Baltic Sea)
}

\author{
C. Berndmeyer ${ }^{1}$, V. Thiel ${ }^{1}$, O. Schmale ${ }^{2}$, N. Wasmund ${ }^{2}$, and M. Blumenberg ${ }^{1, *}$ \\ ${ }^{1}$ Geobiology Group, Geoscience Center, Georg August University Göttingen, Goldschmidtstr. 3, 37077 Göttingen, Germany \\ ${ }^{2}$ Leibniz Institute for Baltic Sea Research Warnemünde (IOW), Seestr. 15, 18199 Rostock-Warnemünde, Germany \\ * now at: Federal Institute for Geosciences and Natural Resources (BGR), Stilleweg 2, 30655 Hanover, Germany
}

Correspondence to: C. Berndmeyer (christine.berndmeyer@geo.uni-goettingen.de)

Received: 28 May 2014 - Published in Biogeosciences Discuss.: 25 June 2014

Revised: 28 October 2014 - Accepted: 29 October 2014 - Published: 11 December 2014

\begin{abstract}
The water column of the Landsort Deep, central Baltic Sea, is stratified into an oxic, suboxic, and anoxic zone. This stratification controls the distributions of individual microbial communities and biogeochemical processes. In summer 2011, particulate organic matter was filtered from these zones using an in situ pump. Lipid biomarkers were extracted from the filters to establish water-column profiles of individual hydrocarbons, alcohols, phospholipid fatty acids, and bacteriohopanepolyols (BHPs). As a reference, a cyanobacterial bloom sampled in summer 2012 in the central Baltic Sea Gotland Deep was analyzed for BHPs. The biomarker data from the surface layer of the oxic zone showed major inputs from cyanobacteria, dinoflagellates, and ciliates, while the underlying cold winter water layer was characterized by a low diversity and abundance of organisms, with copepods as a major group. The suboxic zone supported bacterivorous ciliates, type I aerobic methanotrophic bacteria, sulfate-reducing bacteria, and, most likely, methanogenic archaea. In the anoxic zone, sulfate reducers and archaea were the dominating microorganisms as indicated by the presence of distinctive branched fatty acids: archaeol and pentamethylicosane (PMI) derivatives, respectively. Our study of in situ biomarkers in the Landsort Deep thus provided an integrated insight into the distribution of relevant compounds and describes useful tracers to reconstruct stratified water columns in the geological record.
\end{abstract}

\section{Introduction}

The Baltic Sea is a brackish marine marginal sea with a maximum depth of $459 \mathrm{~m}$ in the Landsort Deep (western central Baltic Sea; Matthäus and Schinke, 1999; Reissmann et al., 2009; Fig. 1). A positive freshwater budget and saltwater inflows from the North Sea through Skagerrak and Kattegat lead to a permanent halocline that stratifies the water column of the central Baltic Sea at about $60 \mathrm{~m}$ water depth (Reissmann et al., 2009). Major saltwater inflows, as detected in 1993 and 2003, sporadically disturb the stratification in the eastern central Baltic Sea and oxygenate the suboxic zone and deep water. These inflows, however, rarely reach the western central Baltic Sea. Even the strong inflow from 1993 had only minor effects on Landsort Deep, where stagnating conditions prevailed throughout (Bergström and Matthäus, 1996). Therefore, the Landsort Deep offers stable environments for microbial life within the oxic, suboxic, and anoxic zones and provides an excellent study site for the investigation of biomarker inventories that specify stratified water columns.

The Black Sea, although much larger in size, is comparable with the Landsort Deep with respect to the existence of a permanently anoxic deep-water body. Two comprehensive in situ biomarker reports gave a wide-ranging overview of various biomarkers and their producers in the Black Sea water column and identified a close coupling of microorganisms to biogeochemically defined water layers (Wakeham et al., 2007, 2012). Several other in situ biomarker water-column studies exist, but they were usually focused on certain aspects, for example anaerobic and aerobic methanotrophy 


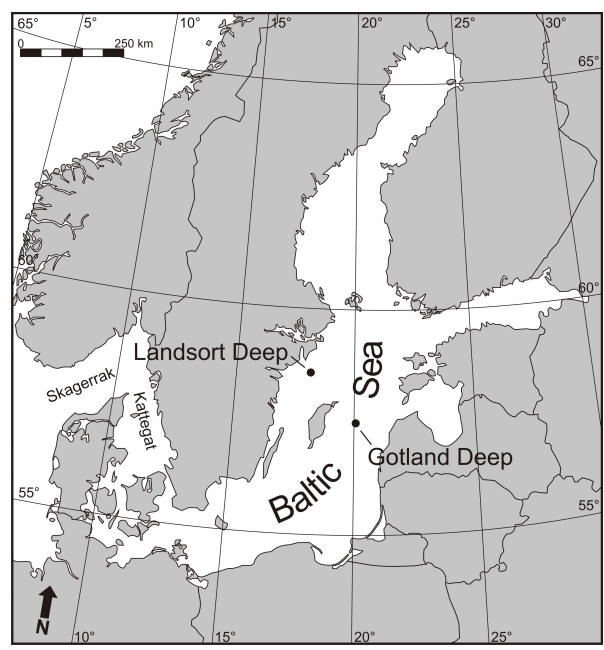

Figure 1. Map showing the sampling locations in the central Baltic Sea.

(Schouten et al., 2001; Schubert et al., 2006; Blumenberg et al., 2007; Sáenz et al., 2011; Xie et al., 2014, and others).

For the Baltic Sea water column, biomarker knowledge is limited as most studies so far were focused on pollutionrelated compounds (e.g., Beliaeff and Burgeot, 2001; Lehtonen et al., 2006; Hanson et al., 2009). Recently, we reported the water-column distributions and ${ }^{13} \mathrm{C}$-content of individual bacteriohopanepolyols (BHPs) and phospholipid fatty acids (PLFA) from the Gotland Deep, located about $150 \mathrm{~km}$ SE of the Landsort Deep in the eastern central Baltic Sea. These studies were aimed at microbial methane turnover and confirmed the importance of the Baltic Sea suboxic zone for bacterial methane oxidation (Schmale et al., 2012; Berndmeyer et al., 2013; Jakobs et al., 2014). The theoretical possibility of sulfate-dependent methane oxidation in the anoxic zone was also stated (Jakobs et al., 2014) but still remains to be proven for the central Baltic Sea water column.

Because the eastern central Baltic Sea is regularly disturbed by lateral intrusions in intermediate water depths (Jakobs et al., 2013), we chose the more stable Landsort Deep in the western central Baltic Sea as a sampling site for this biomarker study. Furthermore, published genetic studies reporting on prokaryotes and the related metabolisms in the water column of the Landsort Deep (Labrenz et al., 2007; Thureborn et al., 2013) provide a background to which the organic geochemical results can be advantageously related. The depth profiles of biomarkers from this setting not only reveal how actual biogeochemical processes are reflected by lipid abundances, distributions, and stable carbon isotope signatures, they also provide reference data for the reconstruction of past water columns using biomarkers from the sedimentary record.

\section{Materials and methods}

\subsection{Samples}

Samples were taken during cruise 06EZ/11/05 of R/V Elisabeth Mann Borghese in summer 2011. The Landsort Deep is located north of Gotland $\left(58^{\circ} 35.0^{\prime} \mathrm{N}, 18^{\circ} 14.0^{\prime} \mathrm{E}\right.$; Fig. 1). A Seabird sbe911+ CTD (conductivity, temperature, density) system and a turbidity sensor ECO FLNTU (WET Labs) were used for continuous water-column profiling. Oxygen and hydrogen sulfide concentrations were measured colometrically with Winkler's method, respectively (Grasshoff et al., 1983). Filter samples of 65 to $195 \mathrm{~L}$ obtained from 10, 65, $70,80,90,95$, and $420 \mathrm{~m}$ water depth were taken with an in situ pump, and particulate material was filtered onto precombusted glass microfiber filters $(\varnothing 30 \mathrm{~cm} ; 0.7 \mu \mathrm{m}$ pore size; Munktell \& Filtrak GmbH, Germany). Filters were freezedried and kept frozen at $-20{ }^{\circ} \mathrm{C}$ until analysis.

A cyanobacterial bloom was sampled in summer 2012 on cruise M87/4 of R/V Meteor at the Gotland Deep $\left(57^{\circ} 19.2^{\prime} \mathrm{N}, 20^{\circ} 03.0^{\prime} \mathrm{E}\right.$; Fig. 1$)$, east of Gotland. Water samples of $10 \mathrm{~L}$ were taken at $1 \mathrm{~m}$ water depth and filtered with a $20 \mu \mathrm{m}$ net. The samples were centrifuged and the residue freeze-dried. Samples were kept frozen at $-20^{\circ} \mathrm{C}$ until analysis.

\subsection{Bulk CNS analysis}

Three pieces $(\varnothing 1.2 \mathrm{~cm})$ from different zones of the filters were combusted together with $\mathrm{V}_{2} \mathrm{O}_{5}$ in a EuroVector EuroEA Elemental Analyzer. Particulate matter in the Baltic Sea was reported to be free of carbonate (Schneider et al., 2002), and, thus, the filters were not acidified prior to analysis. C, N, and S contents were calculated by comparison with peak areas from standards. Standard deviations were $\pm 2 \%$ for $\mathrm{C}$ and $\pm 5 \%$ for $\mathrm{N}$ and $\mathrm{S}$.

\subsection{Lipid analysis}

Three quarters of each filter were extracted $(3 \times 20 \mathrm{~min})$ with dichloromethane (DCM) / methanol $(\mathrm{MeOH})(40 \mathrm{~mL} ; 3: 1$, $v: v$ ) in a CEM Mars 5 microwave (Matthews, NC, USA) at $60^{\circ} \mathrm{C}$ and $800 \mathrm{~W}$. The freeze-dried residue of the cyanobacterial bloom was extracted $(3 \times 10 \mathrm{~min})$ with $\mathrm{DCM} / \mathrm{MeOH}$ $(10 \mathrm{~mL} ; 3: 1, v: v)$ and ultrasonication. All extracts were combined.

An aliquot of each filter extract and the bloom extract was acetylated using $\mathrm{Ac}_{2} \mathrm{O}$ and pyridine $(1: 1, v: v)$ for $1 \mathrm{~h}$ at $50{ }^{\circ} \mathrm{C}$ and then overnight at room temperature. The mixture was dried under vacuum and analyzed for BHPs using liquidchromatography-mass-spectrometry (LC-MS).

Another aliquot of each filter extract was separated into a hydrocarbon (F1), an alcohol and ketone (F2), and a polar fraction (F3) using column chromatography. The column $(\varnothing$ ca. $1 \mathrm{~cm}$ ) was filled with $7.5 \mathrm{~g}$ silica gel 60 ; samples were dried on ca. $500 \mathrm{mg}$ silica gel 60 and placed on the column. 
The fractions were eluted with $30 \mathrm{~mL} n$-hexane / DCM 8 : $2(v: v, \mathrm{~F} 1), 30 \mathrm{~mL} \mathrm{DCM} / \mathrm{EtOAC} 9: 1(v: v, \mathrm{~F} 2)$, and $100 \mathrm{~mL} \mathrm{DCM} / \mathrm{MeOH} 1: 1,(v: v)$ followed by an additional $100 \mathrm{~mL} \mathrm{MeOH}(\mathrm{F} 3)$. F2 was dried and derivatized using a BSTFA / pyridine $3: 2(v: v)$ mixture for $1 \mathrm{~h}$ at $40^{\circ} \mathrm{C}$. A total of $50 \%$ of the polar fraction $\mathrm{F} 3$ was further fractionated to obtain PLFA (F3.3) according to Sturt et al. (2004). Briefly, this entails filling the column with $2 \mathrm{~g}$ silica gel 60 and storing it at $200{ }^{\circ} \mathrm{C}$ until use. The F3 aliquot was dried on ca. $500 \mathrm{mg}$ silica gel 60 and placed on the column. After successive elution of the column with $15 \mathrm{~mL}$ DCM and $15 \mathrm{~mL}$ acetone, the PLFA fraction was eluted with $15 \mathrm{~mL} \mathrm{MeOH}$ (F3.3). F3.3 was transesterified using trimethylchlorosilane (TMCS) in $\mathrm{MeOH}(1: 9 ; v: v)$ for $1 \mathrm{~h}$ at $80^{\circ} \mathrm{C}$. In the resulting fatty acid methyl ester (FAME) fractions, doublebond positions in monounsaturated compounds were determined using dimethyldisulfide (DMDS; Carlson et al., 1989; Gatellier et al., 1993). The samples were dissolved in $200 \mu \mathrm{L}$ DMDS, $100 \mu \mathrm{L} n$-hexane, and $30 \mu \mathrm{L} \mathrm{I}_{2}$ solution $\left(60 \mathrm{mg} \mathrm{I}_{2}\right.$ in $1 \mathrm{~mL} \mathrm{Et}_{2} \mathrm{O}$ ) and derivatized at $50^{\circ} \mathrm{C}$ for $48 \mathrm{~h}$. Subsequently, $1 \mathrm{~mL}$ of $n$-hexane and $200 \mu \mathrm{L}$ of $\mathrm{NaHSO}_{4}$ ( $5 \%$ in water) were added and the $n$-hexane extract was pipetted off. The procedure was repeated 3 times, and the $n$-hexane extracts were combined, dried on ca. $500 \mathrm{mg}$ silica gel 60 and put onto a small column (ca. $1 \mathrm{~g}$ silica gel 60). For cleaning, the $n$-hexane extract was eluted with 10 dead volumes of DCM. F1, F2, F3.3, and the samples treated with DMDS were analyzed using gas-chromatography-mass-spectrometry (GCMS).

\subsection{Gas-chromatography-mass-spectrometry (GC-MS) and GC-combustion isotope ratio mass spectrometry (GC-C-IRMS)}

GC-MS was performed using a Varian CP-3800 chromatograph equipped with a Phenomenex Zebron ZB-5MS fused silica column $(30 \mathrm{~m} \times 0.32 \mathrm{~mm}$; film thickness $0.25 \mu \mathrm{m})$ coupled to a Varian 1200L mass spectrometer. Helium was used as a carrier gas. The temperature program started at $80^{\circ} \mathrm{C}(3 \mathrm{~min})$ and ramped up to $310^{\circ} \mathrm{C}$ (held $25 \mathrm{~min}$ ) with $4^{\circ} \mathrm{C} \min ^{-1}$. Compounds were assigned by comparing mass spectra and retention times to published data. Concentrations were determined by comparison with peak areas of squalane (F2 and F3) and $n$-eicosane-D42 (F1) as internal standards.

Compound-specific stable carbon isotope ratios of biomarkers in F2 and F3.3 were measured (twice) using a Thermo Trace gas chromatograph coupled to a Thermo Delta Plus isotope ratio mass spectrometer. The GC was operated under the same conditions and with the same column as for GC-MS. The combustion reactor contained $\mathrm{CuO}, \mathrm{Ni}$, and $\mathrm{Pt}$ and was operated at $940^{\circ} \mathrm{C}$. Isotopic compositions are reported in standard delta notation relative to the Vienna PeeDee Belemnite (V-PDB) and were calculated by comparison with an isotopically known $\mathrm{CO}_{2}$ reference gas. GC-CIRMS precision and linearity was checked daily using an ex- ternal $n$-alkane isotopic standard (provided by A. Schimmelmann, Indiana University).

\subsection{Liquid-chromatography-mass-spectrometry (LC-MS)}

LC-MS was performed using a Varian Prostar Dynamax high-performance liquid chromatography (HPLC) system fitted with a Merck Lichrocart (Lichrosphere 100; reversed phase $\left.(\mathrm{RP}) \mathrm{C}_{18 \mathrm{e}}\right)$ column $(250 \times 4 \mathrm{~mm})$ and a Merck Lichrosphere pre-column of the same material coupled to a Varian 1200L triple quadrupole mass spectrometer (both Varian). The solvents used were $\mathrm{MeOH} /$ water $9: 1(v: v$; solvent $\mathrm{A})$ and $\mathrm{MeOH} /$ propan-2-ol $1: 1$ ( $v: v$; solvent $\mathrm{B})$, and all solvents were Fisher Scientific HPLC grade. The solvent gradient profile was $100 \% \mathrm{~A}(0-1 \mathrm{~min})$ to $100 \% \mathrm{~B}$ at $35 \mathrm{~min}$ and then isocratic to $60 \mathrm{~min}$. The MS was equipped with an atmospheric pressure chemical ionization (APCI) source operated in positive/ion mode (capillary temperature $150^{\circ} \mathrm{C}$, vaporizer temperature $400^{\circ} \mathrm{C}$, corona discharge current $8 \mu \mathrm{A}$, nebulizing gas flow $70 \mathrm{psi}$, auxiliary gas $17 \mathrm{psi}$ ). In SIM (single-ion monitoring) mode, ions obtained from acetylated BHP peaks in the samples were compared to authentic BHP standards with known concentrations (acetylated BHP and aminotriol) to determine BHP concentrations (external calibration). Amino BHPs had a 7 times higher response factor than nonamino BHPs, and concentrations in the samples were corrected accordingly. Comparisons with elution times of previously identified compounds further aided in BHP assignment. The quantification error is estimated to be $\pm 20 \%$.

\subsection{Principle component analysis (PCA)}

PCA was based on the relative abundance of individual components in different water depths and was performed using R (version 3.0.2, 25 September 2013) with the "princomp" module (The R Foundation, 2014).

\section{Results}

\subsection{Physicochemical parameters of the water column}

In summer 2011, the Landsort Deep showed a strong vertical stratification (Fig. 2). The oxic zone consisted of the uppermost $80 \mathrm{~m}$ and was divided by a strong thermocline into a warm surface layer $(\sim 0-10 \mathrm{~m})$ and a cold winter water layer $(\sim 10-60 \mathrm{~m})$. The halocline was located between 60 and $80 \mathrm{~m} . \mathrm{O}_{2}$ concentrations rapidly decreased from $>8 \mathrm{~mL} \mathrm{~L}^{-1}$ at $\sim 50 \mathrm{~m}$ to $<0.2 \mathrm{~mL} \mathrm{~L}^{-1}$ at $\sim 80 \mathrm{~m}$, defining the upper boundary of the suboxic zone (Tyson and Pearson, 1991). $\mathrm{H}_{2} \mathrm{~S}$ was first detected at $83 \mathrm{~m}$. Because $\mathrm{O}_{2}$ concentrations could methodologically only be measured in the complete absence of $\mathrm{H}_{2} \mathrm{~S}$, oxygen could not be traced below this depth. Therefore, the lower boundary of the suboxic zone was defined to be at $90 \mathrm{~m}$, where $\mathrm{H}_{2} \mathrm{~S}$ concentrations sharply 


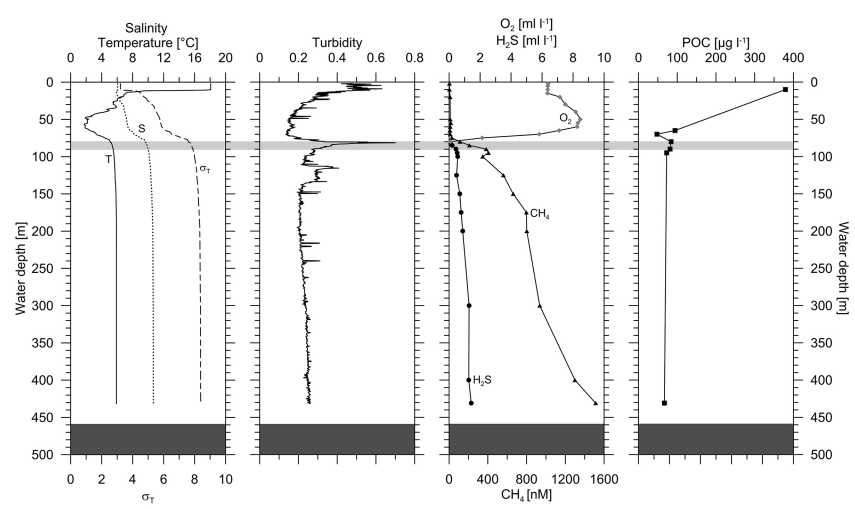

Figure 2. Physicochemical characteristics of the Landsort Deep water column in summer 2011. The suboxic zone is shaded light grey. Temperature and methane data were partially taken from Jakobs et al. (2014).

increased. The upper suboxic zone also showed a sharp peak in turbidity that is possibly caused by the precipitation of $\mathrm{Fe}$ and Mn oxides (Dellwig et al., 2010) or zero-valent sulfur (Kamyshny Jr. et al., 2013) and can be used as an indicator of the $\mathrm{O}_{2}-\mathrm{H}_{2} \mathrm{~S}$ transition (Kamyshny Jr. et al., 2013). The anoxic zone extends from $90 \mathrm{~m}$ to the bottom and is characterized by the complete absence of $\mathrm{O}_{2}$ and high concentrations of $\mathrm{H}_{2} \mathrm{~S}$ and $\mathrm{CH}_{4}$.

$\mathrm{CH}_{4}$ was highest in the deep anoxic zone and decreased strongly towards the suboxic zone but was still present in minor concentrations in the oxic zone. A small $\mathrm{CH}_{4}$ peak was detected at the suboxic-anoxic interface (Fig. 2). Particulate organic carbon (POC) was highest at $10 \mathrm{~m}$ $\left(380 \mu \mathrm{g} \mathrm{L}^{-1}\right)$, decreased to a minimum in the cold winter water layer $\left(48 \mu \mathrm{g} \mathrm{L}^{-1}\right)$, and showed almost constant values of $\sim 70 \mu \mathrm{g} \mathrm{L}^{-1}$ in the suboxic and anoxic zones.

Generally, we follow the zonation of the Landsort Deep water column as given in Jakobs et al. (2014). We regarded the onset of $\mathrm{H}_{2} \mathrm{~S}$ as the top of the anoxic zone, however, as this is better supported by our biomarker data (see below).

\subsection{Lipid analysis}

The PCA analysis separated six groups of biomarkers according to their distribution in the water column (Fig. 3, Sect. 3.2.1-6). Out of these groups, 18 compounds were selected as representative biomarkers, specifying inputs from individual prokaryotes and eukaryotes (with phototrophic, chemotrophic, and/or heterotrophic metabolisms). These biomarkers and their distributions are discussed in detail in Sect. 4.

The concentrations of these compounds are shown in Fig. 4, and compound-specific $\delta^{13} \mathrm{C}$ values are given in Table 1. Apart from the biomarker families revealed by PCA, two compound classes $-n$-alkanes and $n$-alkenes in the sea surface layer - and individual BHPs obtained from the water
Table 1. $\delta^{13} \mathrm{C}$ values of the compounds chosen from the PCA groups. No $\delta^{13} \mathrm{C}$ values were available for Group 4. N.d. stands for "not detectable".

\begin{tabular}{|c|c|c|c|}
\hline \multicolumn{4}{|c|}{$\delta^{13} \mathrm{C}[\% o]$} \\
\hline Compound & oxic zone & suboxic zone & anoxic zone \\
\hline \multicolumn{4}{|l|}{ Group 1} \\
\hline 7-Me-17 : 0 alkane & n.d. & n.d. & n.d. \\
\hline$\beta$-Sitosterol & -29.9 & n.d. & -30.1 \\
\hline $20: 4 \omega 6$ PLFA & -30.1 & -31.7 & -31.6 \\
\hline $20: 5 \omega 3$ PLFA & -29.2 & n.d. & n.d. \\
\hline $16: 1 \omega 7 \mathrm{c}$ PLFA & -30.6 & -28.0 & -28.3 \\
\hline Cholesterol & -26.8 & -28.9 & -31.7 \\
\hline \multicolumn{4}{|l|}{ Group 2} \\
\hline Dinosterol & -29.9 & -30.9 & -32.0 \\
\hline Tetrahymanol & -28.7 & -27.9 & -25.9 \\
\hline Ai-15: 0 PLFA & -29.3 & -32.5 & -34.2 \\
\hline Diploptene & n.d. & n.d. & n.d. \\
\hline \multicolumn{4}{|l|}{ Group 3} \\
\hline $16: 0-18: 1$ Wax ester & -28.1 & -28.2 & n.d. \\
\hline \multicolumn{4}{|l|}{ Group 5} \\
\hline $16: 1 \omega 8$ PLFA & n.d. & -45.4 & n.d. \\
\hline \multicolumn{4}{|l|}{ Group 6} \\
\hline Cholestanol & -27.8 & -28.9 & -30.1 \\
\hline 10-Me-16 : 0 PLFA & n.d. & -32.5 & -35.4 \\
\hline $\mathrm{PMI}+\mathrm{PMI} \Delta$ & n.d. & n.d. & n.d. \\
\hline Archaeol & n.d. & n.d. & - \\
\hline
\end{tabular}

column and a cyanobacterial bloom are reported separately (Fig. 5, Sect. 3.2.7; Fig. 6a, Sect. 3.2.8, respectively).

\subsubsection{Group 1: surface maximum}

The first group is defined by a strong maximum in the surface layer and only minor concentrations in greater depths. A subgroup of 14 compounds exclusively occurs at $10 \mathrm{~m}$ water depth (Fig. 3). For the other compounds, abundance in greater water depths increases towards the $y$ axis. 7-methylheptadecane (52), 24-ethylcholest-5-en-3 $\beta$-ol $(\beta$ -

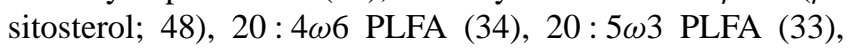
$16: 1 \omega 7 \mathrm{c}$ PLFA (11), and cholest-5-en-3 $\beta$-ol (cholesterol; 44) were taken as representative for Group 1 . Among these compounds, $16: 1 \omega 7$ PLFA and cholesterol showed the highest concentrations (1154 and $594 \mathrm{ng} \mathrm{L}^{-1}$, respectively) and 7methylheptadecane the lowest $\left(6 \mathrm{ng} \mathrm{L}^{-1}\right.$, Fig. 4). Apart from their maximum in the surface layer, the fate of these biomarkers in deeper water layers differed. 7-methylheptadecane exclusively occurred in the surface layer, whereas $20: 4 \omega 6$ was traceable throughout the water column. $\beta$-sitosterol occurred in the surface and the bottom layers. Unlike the other compounds, cholesterol and 20:5 53 PLFA did not show a linear decrease with depth; rather, there are minor occurrences right 
Table 2. Compounds sorted by number as shown in Fig. 3. Compounds chosen for further discussion are marked bold.

\begin{tabular}{|c|c|c|c|c|c|c|c|}
\hline \multicolumn{8}{|c|}{ Compounds: } \\
\hline 1 & 13 : 0 PLFA & 22 & $18: 4$ PLFA & 43 & $26: 0$ PLFA & 64 & $n-\mathrm{C}_{22: 1}$ \\
\hline 2 & $i 14: 0$ PLFA & 23 & $18: 2$ PLFA & 44 & cholesterol & 65 & $n-\mathrm{C}_{22: 0}$ \\
\hline 3 & 14 : 0 PLFA & 24 & $18: 3$ PLFA & 45 & cholestanol & 66 & $n-\mathrm{C}_{23: 1}$ \\
\hline 4 & $i 15$ : 0 PLFA & 25 & $18: 1 \omega 9 \mathrm{c}$ PLFA & 46 & $16: 0-18.1$ wax ester & 67 & $n-\mathrm{C}_{23: 0}$ \\
\hline 5 & ai15 : 0 PLFA & 26 & $18: 1 \omega 7 \mathrm{c}$ PLFA & 47 & $18: 0-18: 1$ wax ester & 68 & $n-\mathrm{C}_{24: 1}$ \\
\hline 6 & $15: 0$ PLFA & 27 & $18: 1 \omega 6 \mathrm{c}$ PLFA & 48 & $\beta$-Sitosterol & 69 & $n-\mathrm{C}_{24: 0}$ \\
\hline 7 & $16: 4$ PLFA & 28 & $18: 1 \omega 5 \mathrm{c}$ PLFA & 49 & dinosterol & 70 & $n-\mathrm{C}_{25: 1}$ \\
\hline 8 & $i$ 16: 0 PLFA & 29 & $18: 0$ PLFA & 50 & tetrahymanol & 71 & $n-\mathbf{C}_{25: 0}$ \\
\hline 9 & $16: 1 \omega 9 \mathrm{c}$ PLFA & 30 & 10-me-18: 0 PLFA & 51 & archaeol & 72 & $n-\mathrm{C}_{26: 1}$ \\
\hline 10 & $16: 1 \omega \mathbf{8 c}$ PLFA & 31 & $i \mathrm{C} 19: 0$ PLFA & 52 & 7-methylheptadecane & 73 & $n-\mathrm{C}_{26}: 0$ \\
\hline 11 & $16: 1 \omega 7 \mathrm{c}$ PLFA & 32 & $19: 0$ PLFA & 53 & PMI + PMI D & 74 & $n-\mathrm{C}_{27: 0}$ \\
\hline 12 & $16: 1 \omega 7 \mathrm{t}$ PLFA & 33 & $20: 5 \omega 3$ PLFA & 54 & diploptene & 75 & $n-\mathrm{C}_{28: 0}$ \\
\hline 13 & $16: 1 \omega 5 \mathrm{c}$ PLFA & 34 & $20: 4 \omega 6$ PLFA & 55 & $n-\mathrm{C}_{17: 1}$ & 76 & $n-\mathrm{C}_{29: 0}$ \\
\hline 14 & $16: 1 \omega 5 \mathrm{t}$ PLFA & 35 & $20: 3$ PLFA & 56 & $n-\mathrm{C}_{17: 0}$ & 77 & $n-\mathrm{C}_{30: 0}$ \\
\hline 15 & $16: 0$ PLFA & 36 & $20: 3$ PLFA & 57 & $n-\mathrm{C}_{18: 0}$ & 78 & $n-\mathrm{C}_{31: 0}$ \\
\hline 16 & 10-me-16 : 0 PLFA & 37 & $20: 1$ PLFA & 58 & $n-\mathrm{C}_{19: 1}$ & 79 & $n-\mathrm{C}_{32: 0}$ \\
\hline 17 & $i \mathrm{C} 17: 0$ PLFA & 38 & $20: 0$ PLFA & 59 & $n-\mathrm{C}_{19: 0}$ & 80 & $n-\mathrm{C}_{33: 0}$ \\
\hline 18 & ai C17 : 0 PLFA & 39 & $22: 6$ PLFA & 60 & $n-\mathrm{C}_{20: 1}$ & 81 & $n-\mathrm{C}_{34: 0}$ \\
\hline 19 & $17: 1$ PLFA & 40 & $22: 4$ PLFA & 61 & $n-\mathrm{C}_{20: 0}$ & 82 & $n-\mathrm{C}_{35: 0}$ \\
\hline 20 & $17: 0$ PLFA & 41 & $22: 0$ PLFA & 62 & $n-\mathrm{C}_{21: 1}$ & 83 & $n-\mathrm{C}_{36}: 0$ \\
\hline 21 & $18: 4$ PLFA & 42 & $24: 0$ PLFA & 63 & $n-\mathrm{C}_{21: 0}$ & 84 & total BHPs \\
\hline
\end{tabular}

above and at the bottom of the suboxic zone. $\delta^{13} \mathrm{C}$ values of all compounds were between -32 and $-26 \%$ o (Table 1 ).

\subsubsection{Group 2: surface and lower suboxic zone maxima}

Like Group 1, Group 2 shows a surface maximum, but it exhibits a stronger emphasis on the lower suboxic zone (Fig. 4). With the exception of $16: 7 \omega 7 \mathrm{t}$, all compounds were chosen for further consideration. $4 \alpha, 23,24$-trimethyl$5 \alpha$-cholest-22E-en-3 $\beta$-ol (dinosterol; 49), and gammacer$3 \beta$-ol (tetrahymanol; 50 ) had their maximum concentration in the surface water (dinosterol: $66 \mathrm{ng} \mathrm{L}^{-1}$; tetrahymanol: $42 \mathrm{ng} \mathrm{L}^{-1}$ ) and were not detectable in the layers below until a sharp second maximum occurred at the bottom of the suboxic zone. Concentrations decreased again below the suboxic zone and remained constantly low in the bottom water. Unlike these compounds, ai 15:0 PLFA (5), total bacteriohopanepolyols (BHPs; 84), and the hopanoid hydrocarbon hop-22(29)-ene (diploptene; 54) showed steadily increasing concentrations throughout the suboxic zone and further increasing concentrations in the anoxic zone. The $\delta^{13} \mathrm{C}$ values of all compounds were between -35 and $-25 \%$ o (Table 1 ).

\subsubsection{Group 3: cold winter water layer maximum}

The third group showed compounds that peaked in the cold winter water layer at $65 \mathrm{~m}$ water depth (Fig. 3). $17: 1 \omega 9$ PLFA (19) only occurred at $70 \mathrm{~m}$ water depth, and $n-\mathrm{C}_{21}$ (61) occurred from 10 to $70 \mathrm{~m}$, with a strong peak at $70 \mathrm{~m}$. The $16: 0-18: 1$ (46; Fig. 4) and 18:0 - 18:1 (47) wax esters

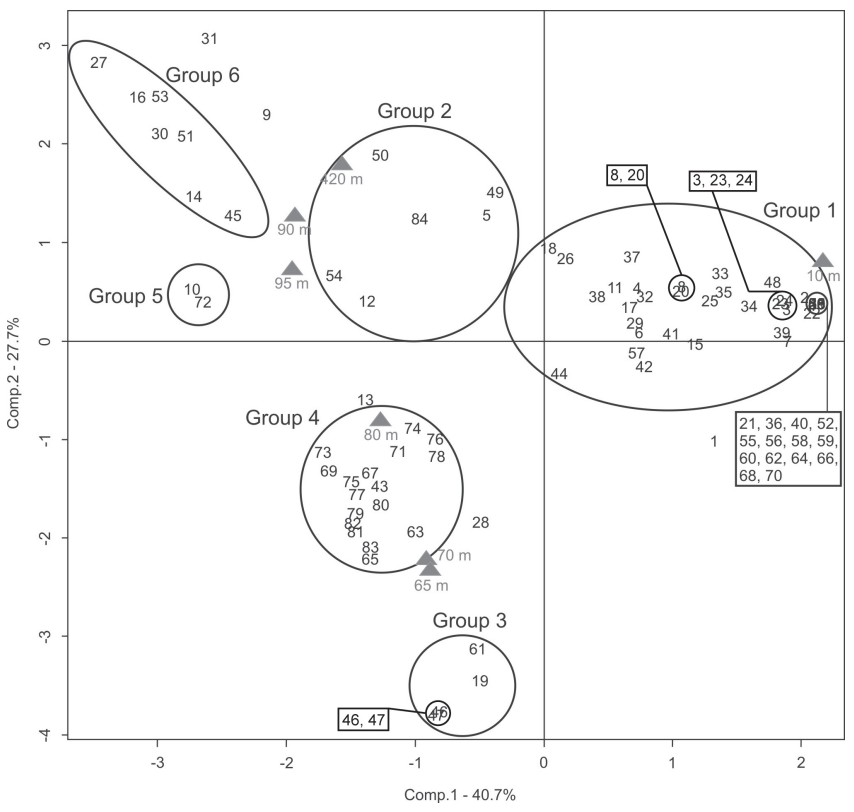

Figure 3. PCA of the relative abundances of compounds in different water depths. Group 1: surface maximum; a subgroup of compounds exclusively occurring at the surface are listed in the box. Group 2: surface and lower suboxic zone maxima. Group 3: cold winter water layer maximum. Group 4: oxic-zone high concentrations. Group 5: suboxic zone maximum. Group 6: absent in oxic zone, bottom layer maximum. Compound names are given in Table 2 . 


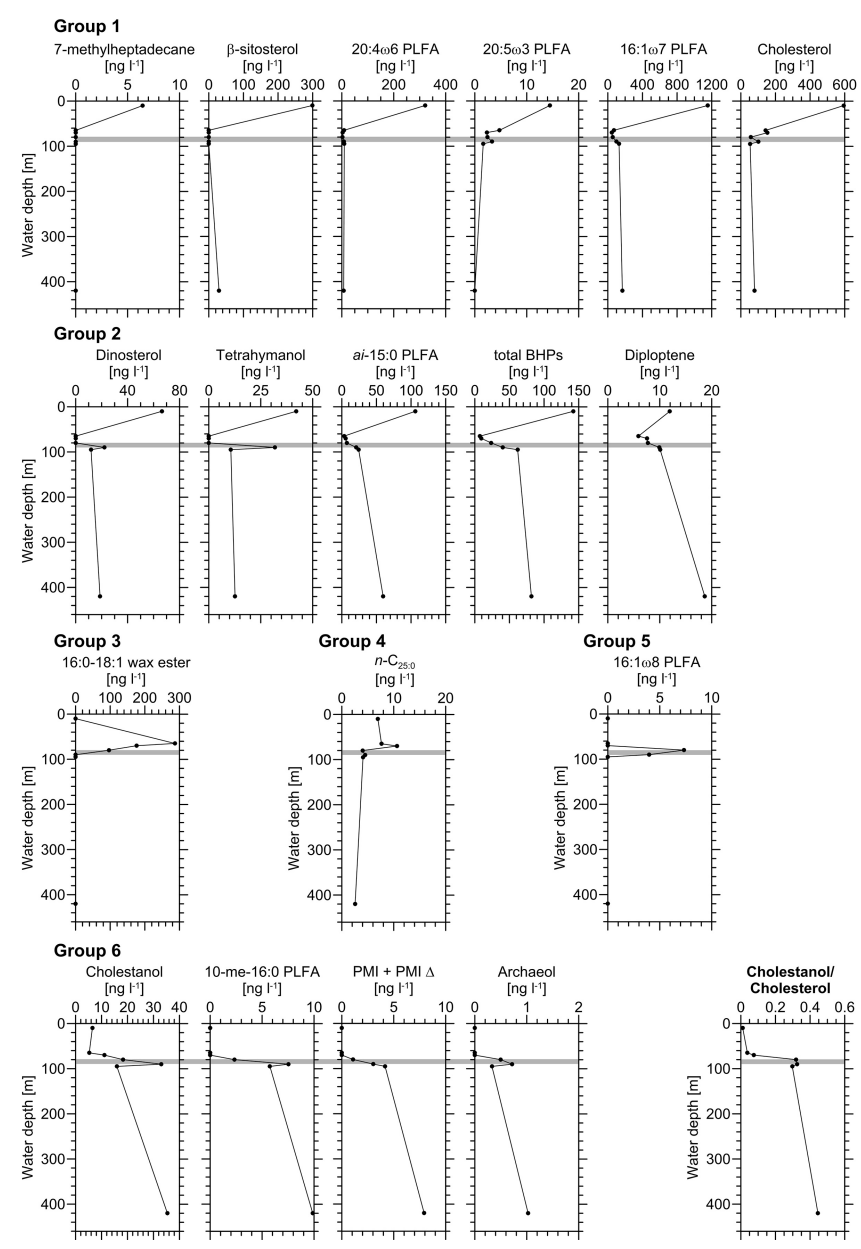

Figure 4. Vertical distribution of biomarkers in the Landsort Deep water column. The suboxic zone is shaded grey.

only occurred from 65 to $80 \mathrm{~m}$, with a maximum at $65 \mathrm{~m}$ ( 287 and $228 \mathrm{ng} \mathrm{L}^{-1}$, respectively). Of Group 3, the $16: 0-18: 1$ wax ester was included in the discussion. $\delta^{13} \mathrm{C}$ values of the wax esters were $\sim-28 \%$ o (Table 1 ).

\subsubsection{Group 4: oxic-zone maximum}

Group 4 consisted exclusively of saturated $n$-alkanes from $n-\mathrm{C}_{21}$ to $n-\mathrm{C}_{36}$ as well as 26:0 PLFA (43). 26:0 PLFA only occurred at $80 \mathrm{~m}$, whereas all other compounds were abundant from the surface to the upper suboxic zone at $80 \mathrm{~m}$ (data not shown). The homologues $n-\mathrm{C}_{27}$ (74), $n-\mathrm{C}_{29}$ (76), and $n-\mathrm{C}_{31}$ (78) show maxima at the surface (21-30 $\mathrm{ng} \mathrm{L}^{-1}$ ). For the other compounds, maxima were either located at 65 or $70 \mathrm{~m}$, with highest concentrations for $n-\mathrm{C}_{25}-n-\mathrm{C}_{36}$ (10-23 ng L ${ }^{-1}$ ). Below $80 \mathrm{~m}$, concentrations dropped to constantly low values. As an example, the depth profile of $n-\mathrm{C}_{25}$ (71) is shown in Fig. 4. $\delta^{13} \mathrm{C}$ values for these compounds could not be obtained.

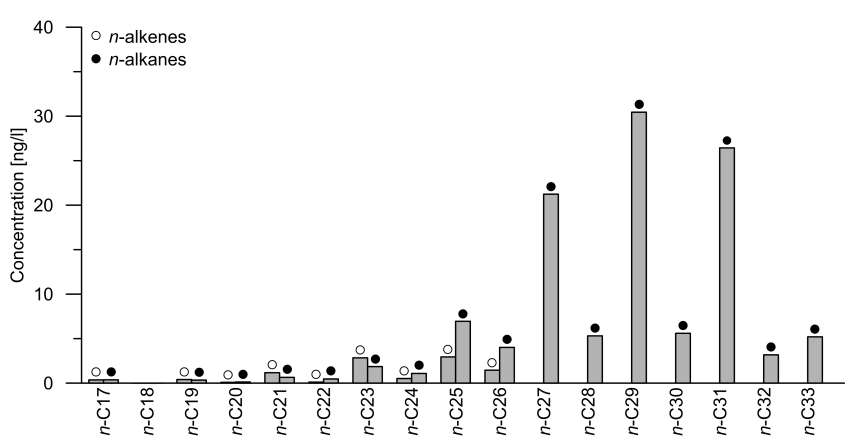

Figure 5. Concentrations of $n$-alkanes and $n$-alkenes in the Landsort Deep surface layer (oxic zone, $10 \mathrm{~m}$ water depth).

\subsubsection{Group 5: suboxic-zone maximum}

Group 5 contained only two compounds: $16: 1 \omega 8$ c PLFA (10) and the $n-\mathrm{C}_{26: 1}$ alkene (72). $n-\mathrm{C}_{26: 1}$ occurred in very low concentrations at $10 \mathrm{~m}$ and peaked at 80 and $95 \mathrm{~m}$ (7$\left.8 \mathrm{ng} \mathrm{L}^{-1}\right) .16: 1 \omega 8 \mathrm{c}$ PLFA occurred only at 80 and $90 \mathrm{~m}$ water depth, with highest values at $80 \mathrm{~m}\left(8 \mathrm{ng} \mathrm{L}^{-1}\right.$; Fig. 4), and was chosen for further discussion. $\delta^{13} \mathrm{C}$ values of this compound were $\sim-45 \%$ o (Table 1$)$.

\subsubsection{Group 6: absent in oxic zone, bottom-layer maximum}

Group 6 consisted of compounds that only occurred in the suboxic zone and below and increased in concentration in the anoxic zone. An exception is $5 \alpha(\mathrm{H})$-cholestan- $3 \beta$ ol (cholestanol; 45), which was also present in the surface layer. 10-me-16: 0 PLFA (16), the irregular $\mathrm{C}_{25}$ isoprenoid 2, 6, 10, 15, 19-pentamethylicosane (PMI) and three unsaturated derivatives thereof (PMI $\Delta ; 53$ ), 2, 3-di-0-isopranyl sn-glycerol diether (archaeol; 51), and cholestanol were considered for further discussion. For all compounds, maxima were detected in the anoxic zone, with highest concentrations observed for cholestanol $\left(35 \mathrm{ng} \mathrm{L}^{-1}\right)$ followed by 10 me-16 : 0 PLFA (10 ng L $\left.{ }^{-1}\right)$, PMI and PMI $\Delta\left(8 \mathrm{ng} \mathrm{L}^{-1}\right)$, and archaeol $\left(1 \mathrm{ng} \mathrm{L}^{-1}\right)$. Compared to other compounds, 10me-16 : 0 PLFA shows a slight ${ }^{13} \mathrm{C}$ depletion in the anoxic zone (-35.4\%o; Table 1). Concentrations of archaeol, PMI, and PMI $\Delta$ were too low to determine $\delta^{13} \mathrm{C}$.

\subsection{7 $n$-Alkanes and $n$-alkenes in the sea surface layer}

The concentrations of $n$-alkanes and $n$-alkenes in the surface sample (10 $\mathrm{m}$ water depth) are given in Fig. 5. The longest $n$-alkane chain was $n-\mathrm{C}_{36}$, and odd carbon numbers dominated over even. Highest concentrations were found for $n$ $\mathrm{C}_{27}\left(21 \mathrm{ng} \mathrm{L}^{-1}\right), n-\mathrm{C}_{29}\left(30 \mathrm{ng} \mathrm{L}^{-1}\right)$, and $n-\mathrm{C}_{31}\left(26 \mathrm{ng} \mathrm{L}^{-1}\right)$. The longest $n$-alkene chain was $n-\mathrm{C}_{26: 1}$, and highest $n$ alkene concentrations were measured for $n-\mathrm{C}_{23: 1}\left(3 \mathrm{ng} \mathrm{L}^{-1}\right)$ and $n-\mathrm{C}_{25: 1}\left(3 \mathrm{ng} \mathrm{L}^{-1}\right)$. 


\subsubsection{Water-column profiles of BHPs}

In the Landsort Deep, seven individual BHPs were identified (Fig. 6a). In all samples, bacteriohopane-32, 33, 34, 35-tetrol (BHT) accounted for the greatest portion of the total BHPs (88-94\%). An as yet uncharacterized BHT isomer, BHT II, was present only below $70 \mathrm{~m}$ and showed its highest relative abundance $(\sim 2 \%)$ between 70 and $90 \mathrm{~m}$. BHT cyclitol ether, BHT glucosamine, and 35-aminobacteriohopane32, 33, 34-triol (aminotriol) were present throughout the water column. BHT cyclitol ether and BHT glucosamine were most abundant in the oxic zone (ca. 1-4\%) but showed only minor abundances $(<1 \%)$ below. Aminotriol was elevated at 65 and $420 \mathrm{~m}$ ( $\sim 7$ and $\sim 5 \%$, respectively). 35Aminobacteriohopane-31, 32, 33, 34-tetrol (aminotetrol) occurred throughout the suboxic and anoxic zones, whereas 35 aminobacteriohopane-30, 31, 32, 33, 34-pentol (aminopentol) was observed only at $90 \mathrm{~m}$ and below. Both aminotetrol and aminopentol showed minor relative abundances of $\sim 2$ and $<1 \%$ of the total BHPs, respectively (Jakobs et al., 2014).

For comparison, the major phytoplankton species from a cyanobacterial bloom in the Gotland Deep (2012) were determined by microscopy (HELCOM manual, 2012) and the particulate organic matter (POM) was analyzed for BHPs. This reference biomass contained mainly Aphanizonemon and, to a smaller extent, Anabaena and Nodularia, which were accompanied by dinoflagellates. Three BHPs were observed in the bloom POM (Fig. 6b). Among these compounds, the most abundant was BHT $(\sim 86 \%)$, followed by BHT cyclitol ether $(\sim 10 \%)$ and BHT glucosamine $(\sim 4 \%)$.

\section{Discussion}

In the following, we discuss several aspects of the biomarker profiles with respect to their significance as tracers for the relevant biota and biogeochemical processes in stratified water columns.

\subsection{Water-column redox zones as reflected by cholestanol / cholesterol ratios}

Different redox states of the Landsort Deep water column and the associated microbial processes are reflected by the profiles of cholesterol and its diagenetic product, cholestanol (Fig. 4; Groups 1 and 6, respectively). Cholesterol is synthesized by various eukaryotic phyto- and zooplankton and higher plants (Parrish et al., 2000) and is abundant in water columns and sediments. In sediments as well as in stratified water columns, stanols are produced from sterols by anaerobic bacterial hydrogenation (Gaskell and Eglinton, 1975; Wakeham, 1989) and by the abiotic reduction of double bonds by reduced inorganic species such as $\mathrm{H}_{2} \mathrm{~S}$ (Hebting et al., 2006; Wakeham et al., 2007). Therefore, cholestanol / cholesterol ratios typically increase under more

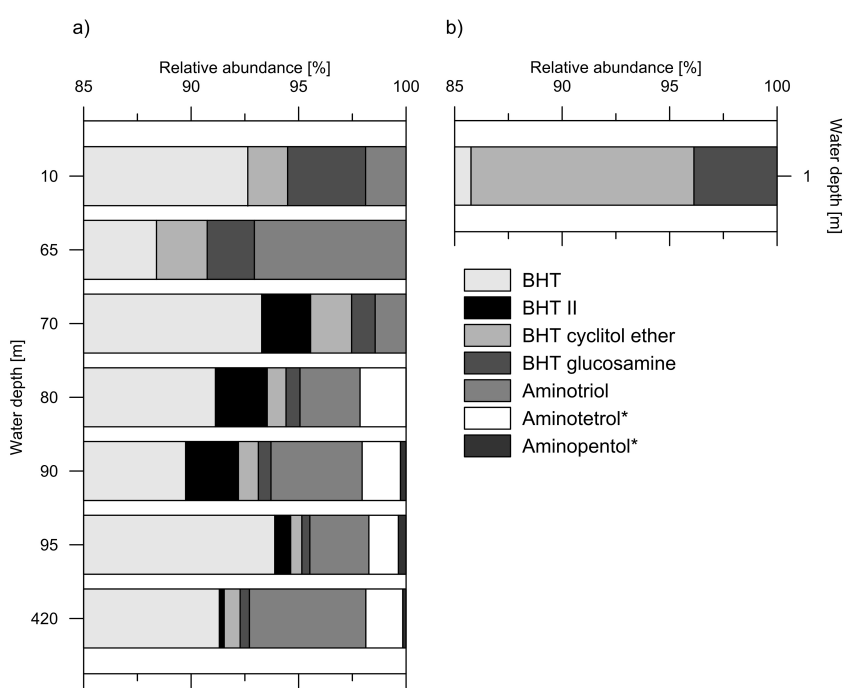

Figure 6. Relative abundances of individual BHPs (as percent of the total) of (a) the Landsort Deep water column and (b) the Gotland Deep cyanobacterial bloom. Note that [\%] axes start at $85 \%$. An asterisk indicates data taken from Jakobs et al. (2014).

reducing conditions. In the Black Sea, low ratios of $\sim 0.1$ were associated with oxygenated surface waters, and the suboxic zone showed ratios between 0.1 and 1 , whereas the anoxic zone revealed values > 1 (Wakeham et al., 2007). In the Landsort Deep, the cholestanol/cholesterol ratios showed a slight increase with depth from the surface towards the suboxic zone but always remained <0.1 (Fig. 4). Below, the values increased to $\sim 0.3$ in the suboxic zone and further to a maximum of 0.45 in the anoxic zone. Whereas the ratios in the Landsort Deep are considerably lower than in the Black Sea, the depth trend still clearly mirrors the changes from oxic to suboxic, and further to anoxic conditions. It is also interesting to note that total cholesterol and cholestanol concentrations in the Landsort Deep were ten- and fourfold higher, respectively, than in the Black Sea (Wakeham et al., 2007).

\subsection{Phototrophic primary production}

As expected, in situ biomarkers for phototrophic organisms were most abundant in the surface layer and are pooled in PCA Group 1. 20:4 46 PLFA is a biomarker traditionally assigned to eukaryotic phytoplankton (Nanton and Castell, 1999; Lang et al., 2011) and organisms grazing thereon, such as protozoa (Findlay and Dobbs, 1993; Pinkart et al., 2002; Risse-Buhl et al., 2011). 20 : $5 \omega 3$ PLFA is known to be a major compound in diatoms (Arao and Marada, 1994; Dunstan et al., 1994), and high concentrations of these PLFAs, as observed in the surface layer of the oxic zone, are in good agreement with such an autochthonous plankton-based source.

7-Methylheptadecane is a characteristic marker for cyanobacteria (Shiea et al., 1990; Köster et al., 1999). Its 
most likely source are members of the subclass Nostocophyceae that were often reported to produce isomeric midchain branched alkanes, including 7-methylheptadecane (Shiea et al., 1990; Hajdu et al., 2007; Liu et al., 2013). Nostocophyceae are key members of the photoautotrophic community in the Baltic Sea. Particularly the filamentous genera Nodularia and Aphanizonemon (see Sect. 3.2.8) and the picocyanobacterium Synechococcus play a major role in blooms during summer time (Stal et al., 2003; Labrenz et al., 2007). The importance of cyanobacteria in the surface layer of the Landsort Deep is further reflected by the presence of $\mathrm{C}_{21: 1}$, $\mathrm{C}_{23: 1}$, and $\mathrm{C}_{25: 1} n$-alkenes (Fig. 5). These compounds have been reported from Anacystis (Gelpi et al., 1970) and Oscillatoria (Matsumoto et al., 1990). Oscillatoria vaucher is also known to occur in the Baltic Sea but is of only minor abundance (Kononen et al., 1996; Vahtera et al., 2007).

Unlike the $n$-alkenes that only occurred in the surface layer, long-chain $n$-alkanes were present in the whole water column, with high abundances in the oxic zone. Long-chain $n$-alkanes with a strong predominance of the odd-numbered $n-\mathrm{C}_{25}$ to $n$ - $\mathrm{C}_{36}$ homologues (Eglinton and Hamilton, 1967; Bi et al., 2005) and $\beta$-sitosterol (Volkman, 1986) are typical components of higher-plant lipids, thus indicating continental runoff and/or aeolian input of terrigenous organic matter into the Landsort Deep. $n$ - $\mathrm{C}_{27}, n-\mathrm{C}_{29}$, and $n-\mathrm{C}_{31}$ showed surface maxima (not shown), indicating similar sources as for $\beta$-sitosterol and a contribution of land plant leaf waxes. Other than $\beta$-sitosterol, most $n$-alkanes peaked between 65 and $70 \mathrm{~m}\left(n-\mathrm{C}_{25}\right.$ for example; Fig. 4). Apart from the surface peaks, this is also true for $n-\mathrm{C}_{27}, n-\mathrm{C}_{29}$, and $n-\mathrm{C}_{31}$. A possible explanation is the accumulation of terrigenous higherplant particles accumulating at the pycnocline, where density differences were highest (MacIntyre et al., 1995)

\subsection{Phototrophic vs. heterotrophic dinoflagellates, and ciliates}

The distribution of dinoflagellates and, most likely, ciliates in the water column is reflected by two specific biomarkers: dinosterol and tetrahymanol (see Sect. 3.2.2, Fig. 4). Dinosterol is mainly produced by dinoflagellates (Boon et al., 1979), although it was also reported in minor abundance from a diatom (Navicula sp., Volkman et al., 1993). The dinosterol concentrations in the Landsort Deep showed a bimodal distribution. The strong peak in the surface layer of the oxic zone probably represents contributions from phototrophic dinoflagellates. Plausible candidates are Peridiniella catenata and Scrippsiella hangoei, both of which are involved in the spring phytoplankton blooms in the central Baltic Sea (Wasmund et al., 1998; Höglander et al., 2004). The latter species was previously reported to produce dinosterol (Leblond et al., 2007). However, $P$. catenata as well as $S$. hangoei are virtually absent below $50 \mathrm{~m}$ water depth (Höglander et al., 2004) and can thus not account for the second peak of dinosterol at the suboxic-anoxic transition zone. An accumulation of surface-derived dinosterol at the bottom of the suboxic zone is unlikely, as the pycnocline, and thus the strongest density discontinuity, is located at $60-70 \mathrm{~m}$ water depth, i.e., about $20 \mathrm{~m}$ further above. Dinosterol is absent in the pycnocline and only occurs from the bottom of the suboxic zone downwards and below. Instead, a likely source of dinosterol at this water depth is represented by heterotrophic dinoflagellates that are abundant in the suboxic zones of the central Baltic Sea (Anderson et al., 2012). Due to their enhanced productivity, these environments provide good conditions to sustain communities of eukaryotic grazers (Detmer et al., 1993). A possible candidate, Gymnodinium beii, was described from the suboxic zones of the central Baltic Sea (Stock et al., 2009). Indeed, several Gymnodinium species are known to be heterotrophs (Strom and Morello, 1998) and some have been reported to produce dinosterol (Mansour et al., 1999). Like cholesterol and $\beta$-sitosterol, dinosterol was also found in the anoxic zone at $400 \mathrm{~m}$ water depth. The production of these compounds at this depth is unlikely, as the synthesis of sterols requires oxygen (Summons et al., 2006). Hence, the observed sterol occurrences probably reflect transport through the water column.

A similar concentration distribution as for dinosterol was observed for tetrahymanol. Tetrahymanol is known to be produced by ferns, fungi, and bacteria, such as the purple nonsulfur bacterium Rhodopseudomonas palustris (Zander et al., 1969; Kemp et al., 1984; Kleemann et al., 1990; Sinninghe Damsté et al., 1995; Eickhoff et al., 2013). Moreover, ciliates ubiquitously produce tetrahymanol as a substitute for cholesterol when grazing on prokaryotes instead of eukaryotes, such as algae (Conner et al., 1968; Boschker and Middelburg, 2002). This is also a feasible scenario for the Baltic Sea, where the ciliate genera Metopus, Strombidium, Metacystis, Mesodinium, and Coleps are abundant in the suboxic zone and at the suboxic-anoxic interface (Detmer et al., 1993; Anderson et al., 2012). Unidentified ciliates also occurred in the anoxic waters of the Landsort Deep (Anderson et al., 2012). Members of the genus Rhodopseudomonas, a possible alternative source of tetrahymanol, have so far not been identified in the suboxic zone (Labrenz et al., 2007; Thureborn et al., 2013). We therefore regard bacterivorous ciliates living under suboxic to anoxic conditions as the most likely source of tetrahymanol in the suboxic zone and below. Likewise, ciliates feeding on chemoautotrophic bacteria were assumed as producers of tetrahymanol in the suboxic zone of the Black Sea (Wakeham et al., 2007). The situation is somewhat different in the surface waters, where tetrahymanol shows its maximum concentrations at $10 \mathrm{~m}$ water depth. Although Rhodopseudomonas and other purple nonsulfur bacteria usually occur under oxygen-deficient conditions, they have been genetically identified in the surface water of the Landsort Deep (Farnelid et al., 2009) and thus have to be considered as potential producers of tetrahymanol. Furthermore, cholesterol is abundant in the surface waters and could be incorporated by ciliates instead of tetrahymanol. However, 
some ciliates seem to prefer prokaryotes as a prey. Sinking agglomerates of cyanobacteria and other bacteria are known to be covered by feeding ciliates (Gast and Gocke, 1988). Hence, in addition to $R$. palustris, ciliates grazing selectively on cyanobacteria would plausibly explain the abundance of tetrahymanol in the shallow waters of the Landsort Deep.

$\delta^{13} \mathrm{C}$ values of tetrahymanol revealed an opposite trend to dinosterol. While dinosterol became isotopically more negative with depth $(-29.9$ to $-32.0 \%$ o $)$, tetrahymanol became more positive $(-28.7$ to $-25.9 \%$ ) and showed its highest $\delta^{13} \mathrm{C}$ values in the anoxic zone. Although ciliates and dinoflagellates are both grazers at the suboxic-anoxic interface, they seem to occupy different ecological niches and feed on different bacterial sources.

\subsection{Heterotrophs in the cold winter water layer}

The only biomarkers with enhanced concentrations in the deep cold winter water layer are wax esters (e.g., 16:0-18: 1 wax ester, Fig. 4) and, to a minor extent, cholesterol and $20: 5 \omega 3$ PLFA. As the pycnocline, and thus a strong density discontinuity, is also located at this depth, an accumulation of settling organic debris containing these compounds has to be considered (MacIntyre et al., 1995). Living organisms, however, may be also be plausible sources. Copepods are known producers of wax esters and cholesterol (Lee et al., 1971; Sargent et al., 1977; Kattner and Krause, 1989; Nanton and Castell, 1999; Falk-Petersen et al., 2002), which are often abundant in density layers, where they feed on accumulated aggregates (MacIntyre et al., 1995). These organisms synthesize wax esters with total chain lengths of between 28 and 44 carbon atoms (Lee et al., 1971; Kattner and Krause, 1989; Falk-Petersen et al., 2002); several of wax esters were present in the Landsort Deep (data not shown in Fig. 4), with roughly the same distribution as the most prominent $16: 0-18: 1$. Although copepods migrate through the water column, particularly those rich in wax esters prefer deep water or nearsurface cold water (Sargent et al., 1977), which is in full agreement with the high amounts of these compounds in the cold winter water layer. Copepods are abundant and diverse in the Baltic Sea, with major species being Pseudocalanus elongatus, Temora longicornis, and Acartia spp. (Möllmann et al., 2000; Möllmann and Köster, 2002). Like the wax esters, the 20:5 3 PLFA shows higher concentrations in the cold winter water layer, but it is also abundant in the surface and at the suboxic-anoxic interface (Fig. 4). Copepods are also known to feed on diatoms and incorporate their specific fatty acids, such as 20:5 53 PLFA, largely unchanged into their own tissue (Kattner and Krause, 1989). Dinoflagellates are also known producers of $20: 5 \omega 3$ PLFA (Parrish et al., 1994; Volkman et al., 1998) and may be an alternative source in the surface layer and at the suboxic-anoxic interface; this is supported by a good correlation with dinosterol at these depths.
Unlike the abovementioned compounds, all other selected biomarkers show particularly low concentrations in the cold winter water layer. This is also true for widespread compounds such as the $16: 1 \omega 7 \mathrm{c}$ PLFA, which is produced by eukaryotes (Pugh, 1971; Shamsudin, 1992) as well as prokaryotes (Parkes and Taylor, 1983; Vestal and White, $1989)$. While a mixed origin of $16: 1 \omega 7 \mathrm{c}$ PLFA has to be assumed for the oxic zone, a bacterial source is more probable in the suboxic zone and in the anoxic zone. Regardless of the biological source, a very low amount of this ubiquitous fatty acid (Fig. 4) indicates that the cold winter water layer of the Landsort Deep does not support abundant planktonic life. Based on microscopy, similar observations have been made for the cold winter water layers of the Gotland, Bornholm, and Gdansk basins (Gast and Gocke (1988) and citations therein).

\subsection{BHPs as indicators for aerobic and anaerobic metabolisms}

Bacteria are the only known source of BHPs (Kannenberg and Poralla, 1999). Although the biosynthesis of BHPs and their precursor, diploptene (both part of Group 2), does not require oxygen, the production of hopanoids was long assumed to be restricted to aerobic bacteria, as reports from facultatively or strictly anaerobic bacteria were initially lacking. More recently, however, planctomycetes (Sinninghe Damsté et al., 2004), metal-reducing Geobacter (Fischer et al., 2005), and sulfate-reducing Desulfovibrio (Blumenberg et al., 2006, 2009, 2012) were identified as anaerobic producers of BHPs. In the Landsort Deep, cyanobacteria are abundant in the surface water layer and may be considered as a major source of BHPs (cf. Talbot et al., 2008; Welander et al., 2010). Evidence for such cyanobacterial BHP contributions may come from our analysis of a Gotland Deep bloom from summer 2012 (see Sect. 3.2.7). BHPs identified in this bloom were BHT, BHT cyclitol ether, and BHT glucosamine (Fig. 6b), which is in line with the BHP composition of the Landsort Deep surface layer (Fig. 6a). These three cyanobacterial BHPs were present throughout the Landsort Deep water column, although they were present in minor amounts in the suboxic zone and below. In addition, the surface layer contained aminotriol that was also present in the whole water column. Aminotriol is an abundant BHP produced by various bacteria (e.g., Talbot and Farrimond (2007) and references therein), indicating that organisms other than cyanobacteria may contribute BHP to the surface layer.

A further notable feature is the occurrence of BHT II at $70 \mathrm{~m}$ and below. The source of BHT II is not fully resolved yet. It was recently related to planctomycetes, especially those performing anaerobic ammonium oxidation (anammox) in sediments (Rush et al., 2014). Anammox bacteria can also be traced by 10-me16:0 PLFA and ladderane PLFAs (not studied here; Sinninghe Damsté et al., 2005; Schubert et al., 2006). 10-me16 : 0 PLFA does indeed show 
a peak in the lower suboxic zone, where BHT II is abundant. However, 10-me16: 0 PLFA may also be contributed by sulfate-reducing bacteria (see Sect. 4.6), and no evidence for anammox has been observed in the water column of the Landsort Deep from molecular biological studies so far (Hietanen et al., 2012; Thureborn et al., 2013). Regardless of the biological source, BHT II was described in stratified water columns of the Arabian Sea, Peru Margin and Cariaco Basin (Sáenz et al., 2011), and the Gotland Deep (Berndmeyer et al., 2013) and has therefore been proposed as a proxy for stratified water columns. This hypothesis has been adopted to reconstruct the development of water-column stratification in the Baltic Sea during the Holocene (Blumenberg et al., 2013).

Like BHT II, aminotetrol and aminopentol are absent from the surface layer (Fig. 6a). Whereas both BHPs are biomarkers for methanotrophic bacteria, the latter typically occurs in type I methanotrophs (Talbot et al., 2001). The presence of type I methanotrophic bacteria is further supported by the co-occurrence of the specific $16: 1 \omega 8$ c PLFA (Nichols et al., 1985; Bowman et al., 1991, 1993) and its considerably depleted $\delta^{13} \mathrm{C}$ value $(-45.4 \%$ ) .

Whereas a major in situ production of BHPs in the suboxic zone is evident from our data, the sources of BHPs in the anoxic zone are more difficult to establish. BHPs in the anoxic zone may partly derive from sinking POM as well as being newly produced by anaerobic bacteria. Sinking POM as a source may apply to BHT cyclitol ether and BHT glucosamine, which seem to derive from cyanobacteria thriving in the oxic zone, as discussed above. Aminotriol, aminotetrol, and aminopentol, however, are known products of sulfate-reducing bacteria (Blumenberg et al., 2006, 2009, 2012) and may have their origin within the anoxic zone. This interpretation is supported by the close correlation of the total BHPs with the ai-15: 0 PLFA, which is considered as indicative of sulfate reducers (see Sect. 4.6; both compounds were part of the same PCA Group 2). Thus, the anoxic zone of the Landsort Deep is likely an active source for BHPs rather than solely being a pool for transiting compounds.

\subsection{Microbial processes in the anoxic zone}

Sulfate-reducing bacteria were traced using ai-15 : 0 PLFA and 10-me-16 : 0 PLFA (Parkes and Taylor, 1983; Taylor and Parkes, 1983; Vainshtein et al., 1992). The high abundance of ai-15 : 0 PLFA in the surface layer (Fig. 4) is surprising at first glance, as sulfate reducers are not supposed to thrive in oxic environments. However, these bacteria were previously reported from oxygenated surface waters of the Gotland Deep, where they were associated with sinking cyanobacterial agglomerates (Gast and Gocke, 1988). 10-Me-16:0 PLFA is otherwise absent from the oxic zone (Fig. 4). This FA was reported to occur in Desulfobacter and Desulfobacula (Taylor and Parkes, 1983; Kuever et al., 2001), both strictly anaerobic organisms (Szewzyk and Pfennig, 1987;
Widdel, 1987; Kuever et al., 2001). Indeed, Desulfobacula toluolica was genetically identified by Labrenz et al. (2007) in suboxic and anoxic waters of the central Baltic Sea.

In addition to the bacterial FA, two archaeal in situ biomarkers, archaeol and PMI, were identified. Archaeol is the most common ether lipid in archaea but is especially abundant in euryarchaeotes, including methanogens (Tornabene and Langworthy, 1979; Koga et al., 1993). Likewise, PMI and its unsaturated derivatives are diagnostic for methanogenic euryarchaeotes (Tornabene et al., 1979; De Rosa and Gambacorta, 1988; Schouten et al., 1997). In the Landsort Deep, both compounds are virtually absent in the oxic zone and increase in abundance with depth through the suboxic zone (Fig. 3). The same trend has been described for PMI in the Black Sea (Wakeham et al., 2007), and the presence of Euryarchaeota in Landsort Deep anoxic waters has recently been proven by Thureborn et al. (2013).

Given the available sample resolution, it is impossible to further elucidate the exact distribution of archaea in the anoxic zone of the Landsort Deep. Likewise, $\delta^{13} \mathrm{C}$ values could not be obtained for archaeol and PMI due to low compound concentrations, which makes statements on inputs of these lipids from archaea involved in the sulfate-dependent anaerobic oxidation of methane (AOM) impossible (cf. Hinrichs et al., 1999; Thiel et al., 2001). Whereas it has been shown that AOM is theoretically possible in the anoxic zone of the Landsort Deep and anaerobic methane consumption has recently been demonstrated to occur (Jakobs et al., 2013), clear evidence for abundant AOM is as yet lacking and requires further investigations focused on the anoxic water bodies of the Baltic Sea.

\section{Conclusions}

The Landsort Deep in the western central Baltic Sea is characterized by a stratified water column. Marine microbial organisms have adapted to the vertical chemical limitations of their ecosystems, and their distributions in the water column can be reconstructed using diverse in situ biomarkers. According to their behavior in the water column, PCA analysis revealed six groups of biomarkers for distinct groups of (micro)organisms and the related biogeochemical processes. Within the oxic zone, a clear preference for the surface layer became obvious for distinctive biomarkers. Among these compounds, 7-methylheptadecane, different alkenes, BHT cyclitol ether, and BHT glucosamine were indicative of the presence of bacterial primary producers, namely cyanobacteria. Dinosterol concentrations and $-\delta^{13} \mathrm{C}$ values revealed a phototrophic dinoflagellate population in the surface waters and a second, heterotrophic community thriving at the suboxic-anoxic interface. Similarly, abundant tetrahymanol at the surface indicated ciliates feeding on cyanobacterial agglomerates, but a second maximum at the suboxic-anoxic interface suggested a further ciliate population that grazed 
on chemoautotrophic bacteria. The cold winter water layer at the bottom of the oxic zone showed only low concentrations of biomarkers and seemed to be avoided by most organisms, except copepods. In contrast, biomarkers obtained from the suboxic zone reflected a high abundance and diversity of eukaryotes and prokaryotes. Whereas $16: 1 \omega 8$ PLFA and aminopentol revealed the presence of type I aerobic methaneoxidizing bacteria, ai-15:0 PLFA, 10-me-16:0, and total BHPs indicated the distribution of sulfate-reducing bacteria in the Landsort Deep water column. The close coupling of ai-15 : 0 PLFA with total BHPs suggests that these bacteria represent a major in situ source for hopanoids in the anoxic zone. The anoxic zone was also inhabited by most likely Euryarchaeota, as shown by the presence of archaeol and PMI and its derivatives. Our study in the water column of the Landsort Deep gives insights into the recent distributions and actual sources of organic matter as reflected by lipid biomarkers. The results may also aid the interpretation of organic matter preserved in the sedimentary record and thus help to better constrain changes in the geological history of the Baltic Sea.

Acknowledgements. We thank the captains and crews of R/Vs Elisabeth Mann Borghese and Meteor for assistance during the cruises. We thank C. Conradt and L. Kammel for laboratory assistance, T. Licha and K. Nödler for help with LC-MS, and N. Cerveau for help with R. We thank S. Bühring and an anonymous reviewer for helpful comments on our manuscript. The German Research Foundation (Deutsche Forschungsgemeinschaft, DFG) is acknowledged for financial support (Grants BL 971/1-3 and 971/3-1)

This Open Access Publication is funded by the University of Göttingen.

Edited by: J. Middelburg

\section{References}

Anderson, R., Winter, C., and Jürgens, K.: Protist grazing and viral lysis as prokaryotic mortality factors at Baltic Sea oxic-anoxic interfaces, Mar. Ecol. Progr., 467, 1-14, 2012.

Arao, T. and Yamada, M.: Biosythesis of polyunsaturated fatty acids in the marine diatom, Phaeodactylum tricornutum, Phytochemistry, 35, 1177-1181, 1994.

Beliaeff, B. and Burgeot, T.: Integrated biomarker response: a useful tool for ecological risk assessment, Environ. Toxicol. Chem., 21, 1316-1322, 2001.

Bergström, S. and Matthäus, W.: Meteorology, hydrology and hydrography, in: Third periodic assessment of the state of the marine environment of the Baltic Sea, 1989-1993; background document, Baltic Sea environment proceedings 64b, HELCOM, Helsinki, 9-18, 1996.

Berndmeyer, C., Thiel, V., Schmale, O., and Blumenberg, M.: Biomarkers for aerobic methanotrophy in the water column of the stratified Gotland Deep (Baltic Sea), Org. Geochem., 55, 103-111, 2013.

Bi, X., Sheng, G., Liu, X., Li, C., and Fu, J.: Molecular and carbon and hydrogen isotopic composition of $n$-alkanes in plant leaf waxes, Org. Geochem., 36, 1405-1417, 2005.

Blumenberg, M., Krüger, M., Nauhaus, K., Talbot, H. M., Oppermann, B. I., Seifert, R., Pape, T., and Michaelis, W.: Biosynthesis of hopanoids by sulfate-reducing bacteria (genus Desulfovibrio), Environ. Microbiol., 8, 1220-1227, 2006.

Blumenberg, M., Seifert, R., and Michaelis, W.: Aerobic methanotrophy in the oxic-anoxic transition zone of the Black Sea water column, Org. Geochem., 38, 84-91, 2007.

Blumenberg, M., Oppermann, B. I., Guyoneaud, R., and Michaelis, W.: Hopanoid production by Desulfovibrio bastinii isolated from oilfield formation water, FEMS Microbiol. Lett., 293, 73-78, 2009.

Blumenberg, M., Hoppert, M., Krüger, M., Dreier, A., and Thiel, V.: Novel findings on hopanoid occurrences among sulfate reducing bacteria: Is there a direct link to nitrogen fixation?, Org. Geochem., 49, 1-5, 2012.

Blumenberg, M., Berndmeyer, C., Moros, M., Muschalla, M., Schmale, O., and Thiel, V.: Bacteriohopanepolyols record stratification, nitrogen fixation and other biogeochemical perturbations in Holocene sediments of the central Baltic Sea, Biogeosciences, 10, 2725-2735, doi:10.5194/bg-10-2725-2013, 2013.

Boon, J. J., Rijpstra, W. I. C., De Lange, F., and De Leeuw, J. W.: Black Sea sterol - a molecular fossil for dinoflagellate blooms, Nature, 277, 125-127, 1979.

Boschker, H. T. S. and Middelburg, J. J.: Stable isotopes and biomarkers in microbial ecology, FEMS Microbiol. Ecol., 40, 85-95, 2002.

Bowman, J. P., Skeratt, J. H., Nichols, P. D., and Sly, L. I.: Phopsholipid fatty acid and lipopolysaccharide fatty acid signature lipids in methane-utilizing bacteria, FEMS Microbiol. Ecol., 85, 15-22, 1991.

Bowman, J. P., Sly, L. I., Nichols, P. D., and Hayward, A. C.: Revised taxonomy of the methanotrophs: Description of Methylobacter gen. nov., emendation of Methylococcus, validation of Methylosinus and Methylocystis species, and a proposal that the family Methylococcaceae includes only the group I methanotrophs, Int. J. Syst. Bacteriol., 43, 735-753, 1993.

Carlson, D. R., Roan, C.-S., Yost, R. A., and Hector, J.: Dimethyl disulfide derivatives of long chain alkenes, alkadiens, and alkatrienes for gas chromatography/mass spectrometry, Anal. Chem., 61, 1564-1571, 1989.

Conner, R. L., Landrey, J. R., Burns, C. H., and Mallory, F. B.: Cholesterol inhibition of pentacyclic triterpenoid biosythesis in Tetrahymena pyriformis, J. Protozool., 15, 600-605, 1968.

De Rosa, M. and Gambacorta, A.: The lipids of archaebacteria, Prog. Lip. Res., 27, 153-175, 1988.

Dellwig, O., Leipe, T., März, C., Glockzin, M., Pollehne, F., Schnetger, B., Yakushev, E. V., Böttcher, M. E., and Brumsack, H.-J.: A new particulate $\mathrm{Mn}-\mathrm{Fe}-\mathrm{P}$-shuttle at the redoxcline of anoxic basins, Geochim. Cosmochim. Ac., 74, 7100-7115, 2010.

Detmer, A. E., Giesenhagen, H. C., Trenkel, V. M., Auf dem Venne, H., and Jochem, F.: Phototrophic and hetreotrophic pico- and nanoplankton in anoxic depths of the central Baltic Sea, Mar Ecol. Progr., 99, 197-203, 1993. 
Dunstan, G. A., Volkman, J. K., Barrett, S. M., Leroi, J.-M., and Jeffrey, S. W.: Essential polyunsaturated fatty acids from 14 species of diatom (Bacillariophyceae), Phytochemistry, 35, 155161, 1994.

Eglinton, G. and Hamilton, R. J.: Leaf epicuticular waxes, Science, 156, 1322-1335, 1967.

Eickhoff, M., Birgel, D., Talbot, H. M., Peckmann, J., and Kappler, A.: Oxidation of $\mathrm{Fe}(\mathrm{II})$ leads to increased $\mathrm{C}_{2}$ methylation of pentacyclic triterpenoids in the anoxygenic phototrophic bacterium Rhodopseudomonas palustris strain TIE-1, Geobiology, 11, 268278, 2013.

Falk-Petersen, S., Dahl, T. M., Scott, C. L., Sargent, J. R., Gulliksen, B., Kwasniewski, S., Hop, H., and Millar, R.-M.: Lipid biomarkers and trophic linkages between ctenophores and copepods in Svalbard waters, Mar. Ecol. Progr., 227, 187-194, 2002.

Farnelid, H., Öberg, T., and Riemann, L.: Identity and dynamics of putative N2-fixing picoplankton in the Baltic proper suggest complex patterns of regulation, Environmental Microbiology Reports, 1, 145-154, 2009.

Findlay, R. H. and Dobbs, F. C.: Quantitative description of microbial communities using lipid analysis, in: Handbook of methods in aquatic microbial ecology, edited by: Cole, J. J., CRC Press, Florida, USA, 271-284, 1993.

Fischer, W. W., Summons, R. E., and Pearson, A.: Targeted genomic detection of biosynthetic pathways: anaerobic production of hopanoid biomarkers by a common sedimentary microbe, Geobiology, 3, 33-40, 2005.

Gaskell, S. J. and Eglinton, G.: Rapid hydrogenation of sterols in a contemporary lacustrine sediment, Nature, 254, 209-211, 1975.

Gast, V. and Gocke, K.: Vertical distribution of number, biomass and size-class spectrum of bacteria in relation to oxic/anoxic conditions in the Central Baltic Sea, Mar. Ecol. Progr., 45, 179-186, 1988.

Gatellier, J.-P. L. A., de Leeuw, J. W., Sinninghe Damsté, J. S., Derenne, S., Largeau, C., and Metzger, P.: A comparative study of macromolecular substances of a Coorongite and cell walls of the extant alga Botryococcus braunii, Geochim. Cosmochim. Ac., 57, 2053-2068, 1993.

Gelpi, E., Schneider, H., Mann, J., and Oró, J.: Hydrocarbons of geochemical significance in microscopic algae, Phytochemistry, 9, 603-612, 1970.

Grasshoff, K., Kremling, K., and Ehrhardt, M.: Methods of seawater analysis, Verlag Chemie, Weinheim, Germany, 75-89, 1983.

Hajdu, S., Höglander, H., and Larsson, U.: Phytoplankton vertical distributions and compositions in Baltic Sea cyanobacterial blooms, Harmful Algae, 6, 189-205, 2007.

Hanson, N., Förlin, L., and Larsson, A.: Evaluation of long-term biomarker data from perch (Perca fluviatilis) in the Baltic Sea suggests increasing exposure to environmental pollutants, Environ. Toxicol. Chem., 28, 364-373, 2009.

Hebting, Y., Schaeffer, P., Behrens, A., Adam, P., Schmitt, G., Schneckenburger, P., Bernasconi, S. M., and Albrecht, P.: Biomarker evidence for a major preservation pathway of sedimentary organic carbon, Science, 312, 1627-1631, 2006.

HELCOM COMBINE: Manual for marine monitoring in the COMBINE programme of HELCOM, Part C, Programme for monitoring of eutrophication and its effects, Annex C-6, Guidelines concerning phytoplankton species composition, abundance and biomass, HELCOM, 310-325, 2012.
Hietanen, S., Jäntti, H., Buizert, C., Jürgens, K., Labrenz, M., Voss, M., and Kuparinen, J.: Hypoxia and nitrogen processing in the Baltic Sea water column, Limnol. Oceanogr., 57, 325-337, 2012.

Hinrichs, K. U., Hayes, J. M., Sylva, S. P., Brewer, P. G., and DeLong, E. F.: Methane-consuming archaebacteria in marine sediments, Nature, 398, 802-805, 1999.

Höglander, H., Larsson, U., and Hajdu, S.: Vertical distribution and settling of spring phytoplankton in the offshore NW Baltic Sea proper, Mar. Ecol. Progr., 283, 15-27, 2004.

Jakobs, G., Rehder, G., Jost, G., Kießlich, K., Labrenz, M., and Schmale, O.: Comparative studies of pelagic microbial methane oxidation within the redox zones of the Gotland Deep and Landsort Deep (central Baltic Sea), Biogeosciences, 10, 7863-7875, doi:10.5194/bg-10-7863-2013, 2013.

Jakobs, G., Holtermann, P., Berndmeyer, C., Rehder, G., Blumenberg, M., Jost, G., Nausch, G., and schmale, O.: Seasonal and spatial methane dynamic in the water column of the central Baltic Sea (Gotland Sea), Cont. Shelf Res., 91, 12-25, 2014.

Kamyshny Jr., A., Yakushev, E. V., Jost, G., and Podymov, O. I.: Role of sulfide oxidation intermediates in the redox balance of the oxic-anoxic interface of the Gotland Deep, Baltic Sea, in: The handbook of environmental chemistry, edited by: Yakushev, E. V., Springer, Berlin Heidelberg, 22, 95-119, 2013.

Kannenberg, E. L. and Poralla, K.: Hopanoid biosythesis and function in bacteria, Naturwissenschaften, 86, 168-176, 1999.

Kattner, G. and Krause, M.: Seasonal variations of lipids (wax esters, fatty acids and alcohols) in calanoid copepods from the North Sea, Mar. Chem., 26, 261-275, 1989.

Kemp, P., Lander, D. J., and Orpin, C. G.: The lipids of the rumen fungus Piromonas communis, J. Gen. Microbiol., 130, 27 37, 1984.

Kleemann, G., Poralla, K., Englert, G., Kjøsen, H., Liaaen-Jensen, S., Neunlist, S., and Rohmer, M.: Tetrahymanol from the phototrophic bacterium Rhodopseudomonas palustris: first report of a gammacerane triterpene from a prokaryote, J. Gen. Microbiol., 136, 2551-2553, 1990.

Koga, Y., Nishihara, M., Morii, H., and Akagawa-Matsushita, M.: Ether polar lipids of methanogenic bacteria: structures, comparative aspects, and biosynthesis, Microbiol. Revs., 57, 164-182, 1993.

Kononen, K., Kuparinen, J., Mäkelä, K., Laanemets, J., Pavelson, J., and Nõmman, S.: Initiation of cyanobacterial blooms in a frontal region at the entrance to the Gulf of Finland, Baltic Sea, Limnol. Oceanogr., 41, 98-112, 1996.

Köster, J., Volkman, J. K., Rullkötter, J., Scholz-Böttcher, B. M., Rethmeier, J., and Fischer, U.: Mono-, di- and trimethylbranched alkanes in cultures of the filamentous cyanobacterium Calothrix scopulorum, Org. Geochem., 30, 1367-1379, 1999.

Kuever, J., Könnecke, M., Galushko, A., and Drzyzga, O.: Reclassification of Desulfobacterium phenolicum as Desulfobacula phenolica comb. nov. and description of strain $\operatorname{Sax}^{\mathrm{T}}$ as Desulfotignum balticum gen. nov., sp. nov., Int. J. Syst. Evol. Microbiol., 51, 171-177, 2001.

Labrenz, M., Jost, G., and Jürgens, K.: Distribution of abundant prokaryotic organsims in the water column of the central Baltic Sea with an oxic-anoxic interface, Aquat. Microb. Ecol., 46, 177-190, 2007.

Lang, I., Hodac, L., Friedl, T., and Feussner, I.: Fatty acid profiles and their distribution patterns in microalgae: a comprehensive 
analysis of more than 2000 strains from the SAG culture collection, BMC Plant Biol., 11, 124-140, 2011.

Leblond, J. D., Anderson, B., Kofink, D., Logares, R., Rengefors, K., and Kremp, A.: Fatty acid and sterol composition of two evolutinary closely related dinoflagellate morphospecies from cold Scandinavian brackish and freshwaters, Eur. J. Phycol., 41, 303311, 2007.

Lee, R. F., Nevenzel, J. C., and Paffenhöfer, G.-A.: Importance of wax esters and other lipids in the marine food chain: phytoplankton and copepods, Mar. Biol., 9, 99-108, 1971.

Lehtonen, K. K., Schiedek, D., Köhler, A., Lang, T., Vuorinen, P. J., Förlin, L., Baršienė, J., Pempkowiak, J., and Gercken, J.: The BEEP project in the Baltic Sea: Overview of results and outline for a regional biological effects monitoring strategy, Mar. Pollut. Bull., 53, 523-537, 2006.

Liu, A., Zhu, T., Lu, X., and Song, L.: Hydrocarbon profiles and phylogenetic analyses of diversified cyanobacterial species, Appl. Energ., 111, 383-393, 2013.

MacIntyre, S., Alldredge, A. L., and Gotschalk, C. C.: Accumulation of marine snow at density discontinuities in the water column, Limnol. Oceanogr., 40, 449-468, 1995.

Mansour, M. P., Volkman, J. K., Jackson, A. E., and Blackburn, S. I.: The fatty acid and sterol composition of five marine dinoflagellates, J. Phycol., 35, 710-720, 1999.

Matsumoto, G. I., Akiyama, M., Watanuki, K., and Torii, T.: Unusual distribution of long-chain $n$-alkanes and $n$-alkenes in Antarctic soil, Org. Geochem., 15, 403-412, 1990.

Matthäus, W. and Schinke, H.: The influence of river runoff on deep water conditions of the Baltic Sea, Hydrobiologia, 393, 1-10, 1999.

Möllmann, C. and Köster, F. W.: Population dynamics of calanoid copepods and the implications of their predation by clupeid fish in the Central Baltic Sea, J. Plankton. Res., 24, 959-977, 2002.

Möllmann, C., Kornilovs, G., and Sidrevics, L.: Long-term dynamics of main mesozooplankton species in the central Baltic Sea, J. Plankton. Res., 22, 2015-2038, 2000.

Nanton, D. A. and Castell, J. D.: The effects of temperature and dietary fatty acids on the fatty acid composition of harpacticoid copepods, for use as a live food for fish larvae, Aquaculture, 175, 167-181, 1999.

Nichols, P. D., Smith, G. A., Antworth, C. P., Hanson, R. S., and White, D. C.: Phospholipid and lipopolysaccharide normal and hydroxy fatty acids as potential signatures for methane-oxidizing bacteria, FEMS Microbiol. Ecol., 0, 327-335, 1985.

Parkes, R. J. and Taylor, J.: The relationship between fatty acid distributions and bacterial respiratory types in contemporary marine sediments, Estuar. Coast. Shelf Science, 16, 173-189, 1983.

Parrish, C. C., Bodennec, G., and Gentien, P.: Time courses of intracellular and extracellular lipid classes in batch cultures of the toxic dinoflagellate, Gymnodinium cf. nagasakiense, Mar. Chem., 48, 71-82, 1994.

Parrish, C. C., Abrajano, T. A., Budge, S. M., Helleur, R. J., Hudson, E. D., Pulchan, K., and Ramos, C.: Lipid and Phenolic Biomarkers in Marine Ecosystems: Analysis and Applications, in: Mar. Chem., edited by: Wangersky, P. J., The Handbook of Environmental Chemistry, Springer Berlin Heidelberg, 193-223, 2000.

Pinkart, H. C., Ringelberg, D. B., Piceno, Y. M., Macnaughton, S. J., and White, D. C.: Biochemical approaches to biomass measurements and community structure analysis, in: Manual of environ- mental microbiology, edited by: Hurt, C. J., ASM Press, Washington, DC, 2, 101-113, 2002.

Pugh, P. R.: Changes in the fatty acid composition of Coscinodiscus eccentricus with cultur-age and salinity, Mar. Biol., 11, 118-124, 1971.

Reissmann, J. H., Burchard, H., Feistel, R., Hagen, E., Lass, H. U., Mohrholz, V., Nausch, G., Umlauf, L., and Wieczorek, G.: Stateof-the-art review on vertical mixing in the Baltic Sea and consequences for eutrophication, Progr. Oceanogr., 82, 47-80, 2009.

Risse-Buhl, U., Trefzeger, N., Seifert, A.-G., Schönborn, W., Gleixner, G., and Küsel, K.: Tracking the autochthonous carbon transfer in stream biofilm food webs, FEMS Microbiol. Ecol., 79, 118-131, 2011.

Rush, D., Sinninghe Damsté, J. S., Poulton, S. W., Thamdrup, B., Garside, A. L., González, J. A., Schouten, S., Jetten, M. S. M., and Talbot, H. M.: Anaerobic ammonium-oxidising bacteria: a biological source of the bacteriohopanetetrol stereoisomer in marine sediments, Geochim. Cosmochim. Ac., 140, 50-64, 2014.

Sáenz, J. P., Wakeham, S. G., Eglinton, T. I., and Summons, R. E.: New constraints on the provenance of hopanoids in the marine geologic record: Bacteriohopanepolyols in marine suboxic and anoxic environments, Org. Geochem., 42, 1351-1362, 2011.

Sargent, J. R., Gatten, R. R., and McIntosh, R.: Wax esters in the marine environment - their occurence, formation, transformation and ultimate fates, Mar. Chem., 5, 573-584, 1977.

Schmale, O., Blumenberg, M., Kießlich, K., Jakobs, G., Berndmeyer, C., Labrenz, M., Thiel, V., and Rehder, G.: Aerobic methanotrophy within the pelagic redox-zone of the Gotland Deep (central Baltic Sea), Biogeosciences, 9, 4969-4977, doi:10.5194/bg-9-4969-2012, 2012.

Schneider, B., Nausch, G., Kubsch, H., and Petersohn, I.: Accumulation of total $\mathrm{CO}_{2}$ during stagnation in the Baltic Sea deep water and its relationship to nutrient and oxygen concentrations, Mar. Chem., 77, 277-291, 2002.

Schouten, S., Van der Maarel, M. J. E. C., Huber, R., and Sinninghe Damsté, J. S.: 2, 6, 10, 15, 19-Pentamethylicosenes in Methanolobus bombayensis, a marine methanogenic archaeon, and in Methanosarcina mazei, Org. Geochem., 26, 409-414, 1997.

Schouten, S., Wakeham, S. G., and Sinninghe Damsté, J. S.: Evidence for anaerobic methane oxidation by archaea in euxinic waters of the Black Sea, Org. Geochem., 32, 1277-1281, 2001.

Schubert, C. J., Coolen, M. J., Neretin, L. N., Schippers, A., Abbas, B., Durisch-Kaiser, E., Wehrli, B., Hopmans, E. C., Damste, J. S., Wakeham, S., and Kuypers, M. M.: Aerobic and anaerobic methanotrophs in the Black Sea water column, Environ. Microbiol., 8, 1844-1856, 2006.

Shamsudin, L.: Lipid and fatty acid composition of microalgae used in Malaysian aquaculture as live food for the early stage of penaeid larvae, J. Appl. Phycol., 4, 371-378, 1992.

Shiea, J., Brassel, S. C., and Ward, D. M.: Mid-chain branched mono- and dimethyl alkanes in hot spring cyanobacterial mats: A direct biogenic source for branched alkanes in ancient sediments?, Org. Geochem., 15, 223-231, 1990.

Sinninghe Damsté, J. S., Kenig, F., Koopmans, M. P., Köster, J., Schouten, S., Hayes, J. M., and de Leeuw, J. W.: Evidence for gammacerane as an indicator of water column stratification, Geochim. Cosmochim. Ac., 59, 1895-1900, 1995. 
Sinninghe Damsté, J. S., Rijpstra, W. I. C., Schouten, S., Fuerst, J. A., Jetten, M. S. M., and Strous, M.: The occurrence of hopanoids in planctomycetes: implications for the sedimentary biomarker record, Org. Geochem., 35, 561-566, 2004.

Sinninghe Damsté, J. S., Rijpstra, Geenevasen, J. A. J., Strous, M., and Jetten, M. S. M.: Structural identification of ladderane and other membrane lipids of planctomycetes capable of anaerobic ammonium oxidation (anammox), FEBS J., 272, 4270-4283, 2005.

Stal, L. J., Albertano, P., Bergmann, B., von Bröckel, K., Gallon, J. R., Hayes, P. K., Sivonen, K., and Walsby, A. E.: BASIC: Baltic Sea cyanobacteria. An investigation of the structure and dynamics of water blooms of cyanobacteria in the Baltic Sea - responses to a changing environment, Cont. Shelf Res., 23, 16951714, 2003.

Stock, A., Jürgens, K., Bunge, J., and Stoeck, T.: Protistan diversity in suboxic and anoxic waters of the Gotland Deep (Baltic Sea) as revealed by $18 \mathrm{~S}$ rRNA clone libraries, Aquat. Microb. Ecol., 55, 267-284, 2009.

Strom, S. L. and Morello, T. A.: Comparative growth rates and yields of ciliates and heterotrophic dinoflagellates, J. Plankton. Res., 20, 571-584, 1998.

Summons, R., Bradley, A. S., Jahnke, L. L., and Waldbauer, J. R.: Steroids, triterpenoids and molecular oxygen, Phil. Trans. R. Soc. B, 361, 951-968, 2006.

Sturt, H. F., Summons, R. E., Smith, K., Elvert, M., and Hinrichs, K. U.: Intact polar membrane lipids in prokaryotes and sediments deciphered by high-performance liquid chromatography/electrospray ionization multistage mass spectrometry - new biomarkers for biogeochemistry and microbial ecology, Rapid Commun. Mass Sp., 18, 617-628, 2004.

Szewzyk, R. and Pfennig, N.: Complete oxidation of catechol by the strictly anaerobic sulfate-reducing Desulfobacterium catecholicum sp. nov., Arch. Microbiol., 147, 163-168, 1987.

Talbot, H. M. and Farrimond, P.: Bacterial populations recorded in diverse sedimentary biohopanoid distributions, Org. Geochem., 38, 1212-1225, 2007.

Talbot, H. M., Watson, D. F., Murrel, J. C., Carter, J. F., and Farrimond, P.: Analysis of intact bacteriohopanepolyols from methanotrophic bacteria by reversed-phase high-performance liquid chromatography-atmospheric pressure chemical ionisation mass spectrometry, J. Chrom., 921, 175-185, 2001.

Talbot, H. M., Summons, R. E., Jahnke, L. L., Cockell, C. S., Rohmer, M., and Farrimond, P.: Cyanobacterial bacteriohopanepolyol signatures from cultures and natural environmental settings, Org. Geochem., 39, 232-263, 2008.

Taylor, J. and Parkes, J.: The cellular fatty acids of the sulphatereducing bacteria, Desulfobacter sp., Desulfobulbus sp. and Desulfovibrio desulfuricans, J. Gen. Microbiol., 129, 33033309, 1983.

The R Foundation For Statistical Computing, R: A language and environment for statistical computing, $\mathrm{R}$ website, available at: http://www.r-project.org/, last access: 15 September 2014.

Thiel, V., Peckmann, J., Richnow, H. H., Luth, U., Reitner, J., and Michaelis, W.: Molecular signals for anaerobic methane oxidation in Black Sea seep carbonates and a microbial mat, Mar. Chem. 73, 97-112, 2001

Thureborn, P., Lundin, D., Plathan, J., Poole, A. M., Sjöberg, B.-M., and Sjöling, S: a metagenomics transect into the deepest point of the Baltic Sea reveals clear stratification of microbial functional capacities, PLOS One, 8, e74983, doi:10.1371/journal.pone.0074983, 2013.

Tornabene, T. G. and Langworthy, T. A.: Diphytanyl and dibiphytanyl glycerol ether lipids of methanogenic archaebacteria, Science, 203, 51-53, 1979.

Tornabene, T. G., Langworthy, T. A., Holzer, G., and Orò, J.: Squalenes, phytanes and other isoprenoids as major neutral lipids of methanogenic and thermoacidophilic "archaebacteria", J. Mol. Evol., 13, 73-83, 1979.

Tyson, R. V. and Pearson, T. H.: Modern and ancient continental shelf anoxia: an overview, Geological Society, London, Special Publications, 58, 1-24, 1991.

Vahtera, E., Conley, D. J., Gustafsson, B. G., Kuosa, H., Pitkänen, H., Savchuk, O. P., Tamminen, T., Viitasalo, M., Voss, M., Wasmund, N., and Wulff, F.: Internal ecosystem feedbacks enhance nitrogen-fixing cyanobacteria blooms and complicate management in the Baltic Sea, Ambio, 36, 186-194, 2007.

Vainshtein, M., Hippe, H., and Kroppenstedt, R. M.: Cellular fatty acid composition of Desulfovibrio species and its use in classification of sulfate-reducing bacteria, Syst. Appl. Microbiol., 15, 554-556, 1992.

Vestal, R. J. and White, D. C.: Lipid analysis in microbial ecology, BioScience, 39, 535-541, 1989.

Volkman, J. K.: A review of sterol markers for marine and terrigenous organic matter, Org. Geochem., 9, 83-99, 1986.

Volkman, J. K., Barrett, S. M., Dunstan, G. A., and Jeffrey, S. W.: Geochemical significance of the occurrence of dinosterol and other 4-methyl sterols in a marine diatom, Org. Geochem., 20, 7-15, 1993.

Volkman, J. K., Barrett, S. M., Blackburn, S. I., Mansour, M. P., Sikes, E. L., and Gelin, F.: Microalgal biomarkers: A review of recent research developments, Org. Geochem., 29, 1163-1179, 1998.

Wakeham, S. G.: Reduction of stenols to stanols in particulate matter at oxic-anoxic boundaries in sea water, Nature, 342, 787-790, 1989.

Wakeham, S. G., Amann, R., Freeman, K. H., Hopmans, E. C., Jørgensen, B. B., Putnam, I. F., Schouten, S., Sinninghe Damsté, J. S., Talbot, H. M., and Woebken, D.: Microbial ecology of the stratified water column of the Black Sea as revealed by a comprehensive biomarker study, Org. Geochem., 38, 2070-2097, 2007.

Wakeham, S. G., Turich, C., Schubotz, F., Podlaska, A., Xiaona, N. L., Varela, R., Astor, Y., Sáenz, J. P., Rush, D., Sinninghe Damsté, J. S., Summons, R. E., Scranton, M. I., Taylor, G. T., and Hinrichs, K. U.: Biomarkers, chemistry and microbiology show chemoautotrophy in a multilayer chemocline in the Cariaco Basin, Deep Sea Res. Pt. I, 163, 133-156, 2012.

Wasmund, N., Nausch, G., and Matthäus, W.: Phytoplankton spring blooms in the southern Baltic Sea - spatio temporal development and long-term trends, J. Plankton. Res., 20, 1099-1117, 1998.

Welander, P. V., Coleman, M., Sessions, A. L., Summons, R. E., and Newman, D. K.: Identification of a methylase required for 2-methylhopanoid production and implications for the interpretation of sedimentary hopanes, PNAS, 107, 8537-8542, 2010.

Widdel, F.: New types of acetate-oxidizing, sulfate-reducing Desulfobacter species, D. hydrogenophilus sp. nov., D. latus sp. nov., and D. curvatus sp. nov., Arch. Microbiol., 148, 286-291, 1987. 
Xie, S., Liu, X.-L., Schubotz, F., Wakeham, S. G., and Hinrichs, K. U.: Distribution of glycerol ether lipids in the oxygen minimum zone of the Eastern Tropical North Pacific Ocean, Org. Geochem., 71, 60-71, 2014.
Zander, J. M., Caspi, E., Pandey, G. N. and Mitra, C. R.: The presence of tetrahymanol in Oleandra wallichii, Phytochemistry, 8 , 2265-2267, 1969 . 